\title{
Development and evaluation of physical properties of a low-cost handheld device for airway clearance therapy
}

\author{
Desenvolvimento e avaliação das propriedades físicas de um dispositivo portátil de baixo \\ custo para bigiene brônquica
}

Desarrollo y evaluación de propiedades físicas de un dispositivo portátil de bajo costo para la bigiene bronquial Cibele Cristine Berto Marques da Silva', Alba Rebeca Nery Comin², Paulo Hilario Nascimento Saldiva ${ }^{3}$,
Milton de Arruda de Martins ${ }^{4}$, Celso Ricardo Fernandes de Carvalho ${ }^{5}$

\begin{abstract}
Several respiratory diseases are characterized by hypersecretion, requiring airway clearance therapy (ACT). Oral high-frequency oscillation (OHFO) devices are effective to enable daily ACT; however, they are still too expensive to become available for low-income patients. We sought to develop a low-cost device (OHFO-LC) and compare its physical properties with those OHFO commercially available (Shaker and Flutter). The OHFO-LC was developed from polyvinyl chloride material and one stainless steel sphere. Pressures and frequencies were measured at flows of 4, 6, 8, 10 and $15 \mathrm{~L} / \mathrm{min}$. Pressures at the mouthpieces were measured by a transducer connected to a microcomputer. The oscillation frequencies were obtained from the graph of the pressure. The frequencies and pressures were compared among groups using one-way Anova and Tukey's post hoc tests, $\mathrm{p} \leq 0.05$. There were no differences among the frequencies of the three devices in all tested flows. The OHFO-LC device showed a higher positive expiratory pressure compared with the Shaker at all tested flows ( $4 \mathrm{~L} / \mathrm{min}: 4.7 \pm 1.2 \mathrm{vs}$. $1.0 \pm 0.2$ $\mathrm{cmH}_{2} \mathrm{O} ; 6 \mathrm{~L} / \mathrm{min}: 8.6 \pm 1.5$ vs. $3.5 \pm 0.5 \mathrm{cmH}_{2} \mathrm{O} ; 8 \mathrm{~L} / \mathrm{min}: 10.8 \pm 1.6$ vs. $5.4 \pm 0.2 \mathrm{cmH}_{2} \mathrm{O} ; 10 \mathrm{~L} / \mathrm{min}: 13.5 \pm 1.2$ vs. $7.7 \pm 0.4 \mathrm{cmH}_{2} \mathrm{O}$; $15 \mathrm{~L} / \mathrm{min}: 14.3 \pm 1.1$ vs. $7.8 \pm 0.2 \mathrm{cmH}_{2} \mathrm{O}$; OHFO-LC vs. Shaker; $\mathrm{p} \leq 0.05$ ) and at 10 and $15 \mathrm{~L} / \mathrm{min}$ compared with Flutter (10 L/min: $13.5 \pm 1.2$ vs. $7.5 \pm 1.2 \mathrm{cmH}_{2} \mathrm{O} ; 15 \mathrm{~L} / \mathrm{min}: 14.3 \pm 1.1$ vs. $8.2 \pm 1.2 \mathrm{cmH}_{2} \mathrm{O}$; OHFO-LC vs. Flutter, $\left.\mathrm{p} \leq 0.05\right)$. The cost of the OHFO-LC device was much lower than both the Shaker
\end{abstract}

and the Flutter. Our results showed that the OHFO-LC had physical properties with similar frequencies but higher pressures than other OHFO devices that are commercially available. Future studies are necessary to evaluate its clinical efficacy.

Keywords | Respiratory Therapy; Airway Management; Chest Wall Oscillation.

RESUMO I Diversas doenças respiratórias são caracterizadas por hipersecreção com necessidade de higiene brônquica (HB). Osciladores orais de alta frequência (OOAF) são dispositivos que promovem HB diária; entretanto, seu custo pode ser inviável para aquisição por pacientes com baixa renda. Os objetivos deste estudo foram: desenvolver um OOAF de baixo custo (OOAF$\mathrm{BC}$ ) e comparar suas propriedades físicas com as dos disponíveis comercialmente (Shaker e Flutter). O OOAF-BC foi desenvolvido com material de polivinil clorido e uma esfera de aço inoxidável. As pressões e frequências foram mensuradas nos fluxos de 4, 6, 8, 10 e 15 L/min. As pressões nos bocais foram medidas por um transdutor conectado ao computador. As frequências de oscilação foram derivadas do gráfico de pressão. A comparação dos dispositivos foi feita por Anova com post hoc de Tukey, $p \leq 0.05$. Não houve diferença entre as frequências dos três dispositivos em todos os fluxos testados. O OOAF-BC apresentou pressão

\footnotetext{
'Universidade de São Paulo (USP) - São Paulo (SP), Brazil. E-mail: ciberto@usp.br. Orcid: 0000-0003-0615-4070 ${ }^{2}$ Clínica Equipe Mais Atitude Mais Bem Estar - Salvador (BA), Brazil. E-mail: albacomin@gmail.com. Orcid: 0000-0002-9393-4237 3Universidade de São Paulo (USP) - São Paulo (SP), Brazil. E-mail: pepino@usp.br. Orcid: 0000-0003-2005-8253 ${ }^{4}$ Universidade de São Paulo (USP) - São Paulo (SP), Brazil. E-mail: mmartins@usp.br. Orcid: 0000-0001-9690-9371 5Universidade de São Paulo (USP) - São Paulo (SP), Brazil. E-mail: cscarval@usp.br. Orcid: 0000-0003-3046-3412
} 
mais alta comparado ao Shaker em todos os fluxos testados (4 L/min: $4,7 \pm 1,2$ vs. $1,0 \pm 0,2 \mathrm{cmH}_{2} \mathrm{O} ; 6 \mathrm{~L} / \mathrm{min}: 8,6 \pm 1,5$ vs. $3,5 \pm 0,5 \mathrm{cmH}_{2} \mathrm{O} ; 8 \mathrm{~L} / \mathrm{min}: 10,8 \pm 1,6$ vs. $5,4 \pm 0.2 \mathrm{cmH}_{2} \mathrm{O} ; 10 \mathrm{~L} / \mathrm{min}$ : $13,5 \pm 1,2$ vs. $7,7 \pm 0.4 \mathrm{cmH}_{2} \mathrm{O} ; 15 \mathrm{~L} / \mathrm{min}: 14,3 \pm 1,1$ vs. $7,8 \pm 0,2 \mathrm{cmH}_{2} \mathrm{O}$; OOAF-BC vs. Shaker; $\mathrm{p} \leq 0.05$ ) e nos fluxos de 10 e $15 \mathrm{~L} / \mathrm{min}$ comparado ao Flutter (10 L/min: $13,5 \pm 1,2$ vs. 7,5 $\pm 1,2 \mathrm{cmH}_{2} \mathrm{O}$; $15 \mathrm{~L} / \mathrm{min}: 14,3 \pm 1,1$ vs. $8,2 \pm 1,2 \mathrm{cmH}_{2} \mathrm{O}$; OOAF-BC vs. Flutter, $\mathrm{p} \leq 0.05$ ). $\mathrm{O}$ custo do OOAF-BC foi pelo menos seis vezes menor. O OOAF$\mathrm{BC}$ apresentou frequências similares e pressões mais altas que os outros OOAF comercialmente disponíveis. Estudos futuros são necessários para avaliar sua eficácia clínica.

Descritores | Terapia Respiratória; Manuseio das Vias Aéreas; Oscilação da Parede Torácica.

RESUMEN | Varias enfermedades respiratorias se caracterizan por hipersecreción, que requiere higiene bronquial (HB). Los osciladores orales de alta frecuencia (OOAF) son dispositivos que promueven la HB diaria; sin embargo, su costo puede no ser factible para la adquisición por parte de pacientes con bajos ingresos. Los objetivos de este estudio fueron desarrollar un OOAF de bajo costo (OOAF-BC) y comparar sus propiedades físicas con las de los disponibles comercialmente (Shaker y Flutter). El OOAF-BC se desarrolló con material de polivinilo clorado y una bola de acero inoxidable. Las presiones y frecuencias se midieron en flujos de 4, 6, 8, 10 y $15 \mathrm{~L} / \mathrm{min}$. Las presiones de la boquilla se midieron mediante un transductor conectado a la computadora. Las frecuencias de oscilación se derivaron del gráfico de presión. Se compararon los dispositivos con la utilización de Anova con post hoc de Tukey, $p \leq 0,05$. No hubo diferencias entre las frecuencias de los tres dispositivos en todos los flujos probados. El OOAF-BC mostró una presión más alta en comparación con Shaker en todos los flujos probados (4 L/min: $4,7 \pm 1,2$ vs. $1,0 \pm 0,2 \mathrm{cmH}_{2} \mathrm{O} ; 6 \mathrm{~L} / \mathrm{min}: 8,6 \pm 1,5$ vs. $3,5 \pm 0,5 \mathrm{cmH}_{2} \mathrm{O} ; 8 \mathrm{~L} / \mathrm{min}$ : $10,8 \pm 1,6$ vs. $5,4 \pm 0,2 \mathrm{cmH}_{2} \mathrm{O} ; 10 \mathrm{~L} / \mathrm{min}: 13,5 \pm 1,2$ vs. $7,7 \pm 0,4 \mathrm{cmH}_{2} \mathrm{O}$; $15 \mathrm{~L} / \mathrm{min}: 14,3 \pm 1,1$ vs. 7,8 $\pm 0,2 \mathrm{cmH}_{2} \mathrm{O}$; OOAF-BC vs. Shaker; $\left.\mathrm{p} \leq 0,05\right)$ y con flujos de 10 y $15 \mathrm{~L} / \mathrm{min}$ en comparación con Flutter $(10 \mathrm{~L} / \mathrm{min}$ : $13,5 \pm 1,2$ vs. $7,5 \pm 1,2 \mathrm{cmH}_{2} \mathrm{O} ; 15 \mathrm{~L} / \mathrm{min}: 14,3 \pm 1,1$ vs. $8,2 \pm 1,2 \mathrm{cmH}_{2} \mathrm{O}$; OOAF-BC vs. Flutter, p $\leq 0,05)$. El costo de OOAF-BC fue al menos seis veces menor. El OOAF-BC mostró frecuencias similares y presiones más altas que otros OOAF disponibles comercialmente. Se necesitan estudios futuros para evaluar su eficacia clínica.

Palabras clave I Terapia Respiratoria; Manejo de la Vía Aérea; Oscilación de la Pared Torácica.

\section{INTRODUCTION}

Several respiratory diseases such as cystic fibrosis, chronic bronchitis and bronchiectasis are characterized by the increased production and accumulation of mucus secretion in the airways, predisposing these patients to recurrent infections throughout life, contributing to airway and parenchymal damage. Airway clearance therapy (ACT) has been a cornerstone in respiratory therapy for the treatment of pulmonary hypersecretion ${ }^{1}$.

There are several techniques of ACT, and some of them such as the slow expiration with glottis opened in lateral posture (ELTGOL, an acronym from the French term l'expiration lente totale glotte ouverte en decubitus lateral), autogenic drainage (AD), active cycle of breathing technique (ACBT) and oral high-frequency oscillation (OHFO) devices can be performed by the patient. In clinical practice, ELTGOL, AD and ACBT require a better understanding of the patient and a longer period of respiratory therapy to promote the intended effect. Additionally, the OHFO devices for secretion clearance are an increasingly used alternative to traditional treatments, being well accepted by patients and allow nonsupervised use ${ }^{2}$, including by adolescents and children ${ }^{3}$.
Besides being portable and practical to assist in daily bronchial hygiene and promote greater independence for the treatment, these devices improve adherence to respiratory therapy ${ }^{4}$. OHFO devices combine two physiological effects: a positive expiratory pressure and vibrations transmitted through the airways that facilitate the removal of secretions and expectoration ${ }^{5}$. Flutter VRP1 (designed by Lindemann ${ }^{6}$ and produced by Axcan Scandipharm Inc., Birmingham, Alabama, USA) and the Shaker (a prototype developed by the NCS Induistria e Comércio, São Paulo, São Paulo, Brazil) are OHFO devices that are commercially available with the same vibration mechanism. Both devices have the shape of a smoking pipe and consist of four parts: (1) a body with a mouthpiece; (2) a conical cavity; (3) a stainless steel sphere; and (4) a protective cap through which expired air flows. The stainless steel sphere provides resistance to exhaled air, opening and closing the air passage and producing pressure oscillations. Simultaneously, it produces a vibration at approximately $15 \mathrm{~Hz}$, compatible with those necessary for the removal of secretions ${ }^{2}$.

OHFO devices promote these benefits but also have disadvantages such as the cost, which is a barrier especially for patients with lower socioeconomic status or those from 
developing countries. In Brazil, the Flutter VRP1 and Shaker devices cost approximately US\$ 50 and US $\$ 20$, respectively. Based on this concern, we describe the development of a low-cost OHFO device for bronchial hygiene similar to those commercially available and compare their physical properties.

\section{METHODOLOGY}

This was an experimental study conducted in two phases. In the first phase, we built an oral high-frequency oscillation (OHFO) device with low-cost materials. In the second phase, the physical properties (oscillation frequencies and positive pressures) were evaluated in a laboratory.

\section{Phase 1: development of a low cost OHFO device (OHFO-LC)}

Materials and assembly: we used the materials below to develop a OHFO-LC: an 0.8 inch length and 3/4 inch diameter polyvinyl chloride (PVC) pipe (A), a 5/8 inch diameter stainless steel sphere (B), a 3/4 inch diameter PVC elbow (C) and a 2 inch length and $3 / 4$ inch diameter PVC pipe (D), as showed in Figure 1.

Polyvinyl chloride (PVC) was chosen because it is an inert and nontoxic low-cost plastic that is malleable, allowing it to be easily molded ${ }^{7}$. The dimensions of the PVC pieces were defined based on the approximate dimensions of the other two OHFO devices we compared in our study. The stainless steel sphere, however, is approximately twice the size of the stainless steel sphere of the other two OHFO devices. This difference is due to the sphere sitting: the Flutter VRP1 and the Shaker spheres sit in a circular cone inside the bowl of the pipe, while the sphere of the OHFO-LC remains in the elbow of a 3/4 inch diameter PVC pipe. The mouthpiece of the OHFO-LC device was molded with a 2 inch length and 3/4 inch diameter PVC pipe by immersing one side in $100^{\circ} \mathrm{C}$ water for approximately 30 seconds. Then, a resin mold ( 2 inch length, 0.75 inch width, 0.3 inch height) was inserted inside the latter PVC pipe piece, following an immersion into cold water (approximately $0^{\circ} \mathrm{C}$ ) to cool the material. At last, the resin mold was removed, standardizing the vertical opening in the mouthpiece to 0.3 inch. The 0.8 inch long $\mathrm{PVC}$ piece aims at preventing the escape of the steel sphere. Two 0.2 inch holes were drilled in this piece, symmetrically and diametrically opposed, with the aid of a drill. These holes facilitate the removal of this PVC piece to enable the cleaning of the equipment. The assembly of the portable equipment was designed to fit part $\mathrm{A}$ into part $\mathrm{C}$ after the introduction of part B (sphere) at one free end of part C. Finally, part $\mathrm{D}$ was fitted to the other free end of part $\mathrm{C}$, as showed in Figure 1.

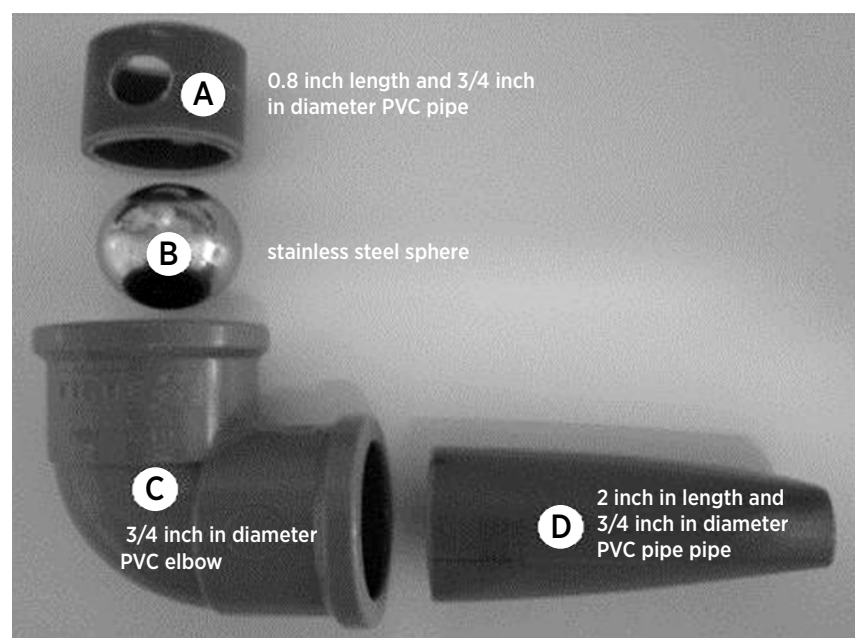

Figure 1. Materials used for development of a low-cost oral highfrequency oscillation (OHFO-LC) device

\section{Phase 2: comparison of the frequencies and positive pressures in the laboratory: OHFO-LC versus the Flutter VRP1 and Shaker devices}

A punctuated orifice was drilled on the right side of every OHFO mouthpiece devices (OHFO-LC, Shaker, and Flutter VRP1), in which a transducer (Validyne DP 45-28-2114) was fitted to quantify the pressure. The airflow sent into the OHFOs was introduced by means of an elastic tube attached in the mouthpiece on one side and in an oxygen cylinder on the other side. A pneumotachograph (Validyne DP 45-16-2114) was attached between the cylinder and the mouthpiece to measure the airflow, as showed in Figure 2.

The pressure and flow transducers recorded values in a physiograph (Gould RS 3400). The data were only collected after the airflow was maintained constant through each mouthpiece at 4, 6, 810 and $15 \mathrm{~L} / \mathrm{min}$. These air flow rates are within the range used by Volsko, DiFiore and Chatburn ${ }^{8}$. The flow and pressure transducers were previously calibrated. We obtained the data using a 12-channel analog-to-digital converter with a sampling frequency of $100 \mathrm{~Hz}$ (DT 2801a, Data Translation) and stored the data on a microcomputer. All the measurements were obtained with the devices at an angle of zero degrees, relative to the workstation. 
The oscillation frequencies were estimated as the average number of cycles obtained during the pressure analysis for every airflow set (from 4 to $15 \mathrm{~L} / \mathrm{min}$ ). All devices were analyzed during the same period, and the values were expressed as cycles per second. The pressure values were obtained using the Anadat 3.1 software.

\section{A: flow transducer B: pressure transducer C: device}

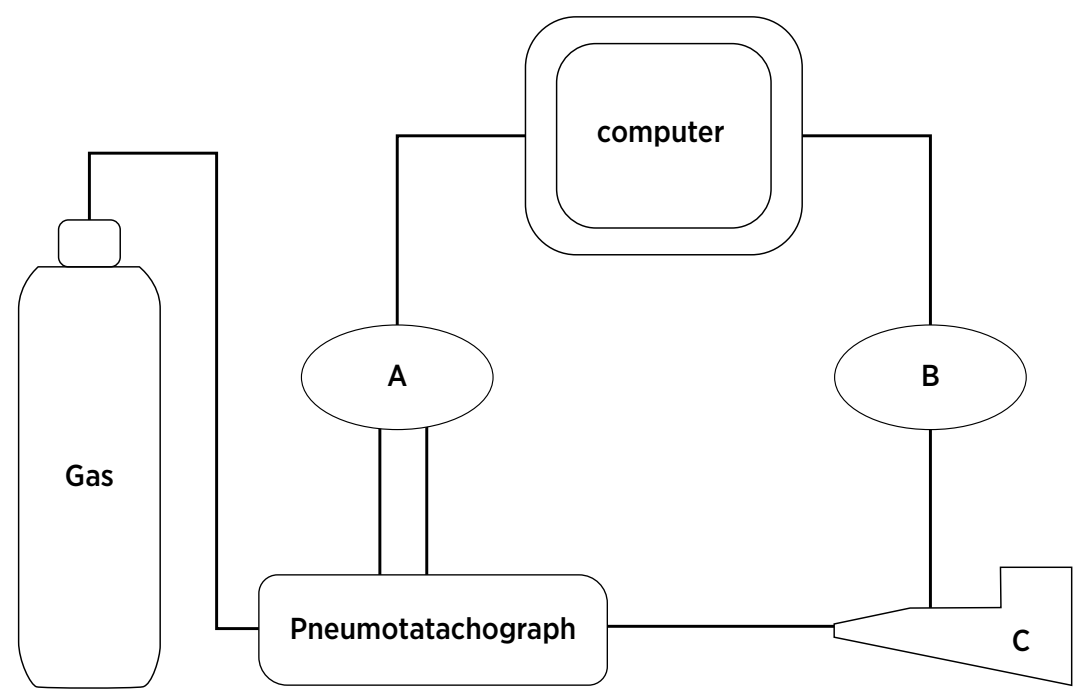

Figure 2. Evaluation of physical properties of oral high-frequency oscillation (OHFO) devices

Data normality was assessed by the KolmogorovSmirnov test. Data were presented as the means and standard deviations. The mean frequencies and positive pressures among the groups were compared using oneway analysis of variance (Anova) with Tukey post-hoc tests. We adopted a 5\% significance level.

\section{RESULTS}

The OHFO-LC final cost was approximately US $\$ 3$ (US\$ 0.5 for the polyvinyl chloride (PVC) material and US $\$ 2.5$ for the stainless steel sphere). This cost is at least 6 times lower than the Shaker (NCS, Brazil) (US\$20) and over 15 times lower than the Flutter (Axcan Scandipharm Inc., USA) (US\$ 50).

There was no difference in the mean frequencies between the OHFO-LC, Shaker and Flutter at any of the tested flow rates $(4 \mathrm{~L} / \mathrm{min}: 13.8 \pm 0.1,11.7 \pm 0.5$, and $12.8 \pm 0.0 \mathrm{~Hz} ; 6 \mathrm{~L} / \mathrm{min}: 14.0 \pm 0.0,13.2 \pm 0.4$, and $14.0 \pm 0.0 \mathrm{~Hz} ; 8 \mathrm{~L} / \mathrm{min}: 14.8 \pm 0.0,14.0 \pm 0.1$, and $13.3 \pm 0.4 \mathrm{~Hz}$; $10 \mathrm{~L} / \mathrm{min}: 14.8 \pm 0.0,13.4 \pm 0.6$, and $14.8 \pm 0.0 \mathrm{~Hz}$; $15 \mathrm{~L} / \mathrm{min}: 14.8 \pm 0.0,14.3 \pm 0.2$, and $15.5 \pm 0.0 \mathrm{~Hz}$; for the OHFO-LC, Shaker and Flutter; $p>0.05$ ), as showed in Figure 3. The OHFO-LC device showed a higher positive expiratory pressure compared with the Shaker at all flows tested ( $4 \mathrm{~L} / \mathrm{min}: 4.7 \pm 1.2$ vs. $1.0 \pm 0.2 \mathrm{cmH}_{2} \mathrm{O} ; 6$ $\mathrm{L} / \mathrm{min}: 8.6 \pm 1.5$ vs. $3.5 \pm 0.5 \mathrm{cmH}_{2} \mathrm{O}$; $8 \mathrm{~L} / \mathrm{min}: 10.8 \pm 1.6$ vs. $5.4 \pm 0.2 \mathrm{cmH}_{2} \mathrm{O} ; 10 \mathrm{~L} / \mathrm{min} ; 13.5 \pm 1.2$ vs. $7.7 \pm 0.4 \mathrm{cmH}_{2} \mathrm{O}$; $15 \mathrm{~L} / \mathrm{min}: 14.3 \pm 1.1$ vs. $7.8 \pm 0.2 \mathrm{cmH}_{2} \mathrm{O}$; respectively; $\mathrm{p} \leq 0.05)$ and at 10 and $15 \mathrm{~L} / \mathrm{min}$ compared with the Flutter (10 L/min: $13.5 \pm 1.2$ vs. $7.5 \pm 1.2 \mathrm{cmH}_{2} \mathrm{O} ; 15 \mathrm{~L} / \mathrm{min}$ : $14.3 \pm 1.1$ vs. $8.2 \pm 1.2 \mathrm{cmH}_{2} \mathrm{O}$; respectively, $\left.\mathrm{p} \leq 0.05\right)$, as showed in Figure 4.

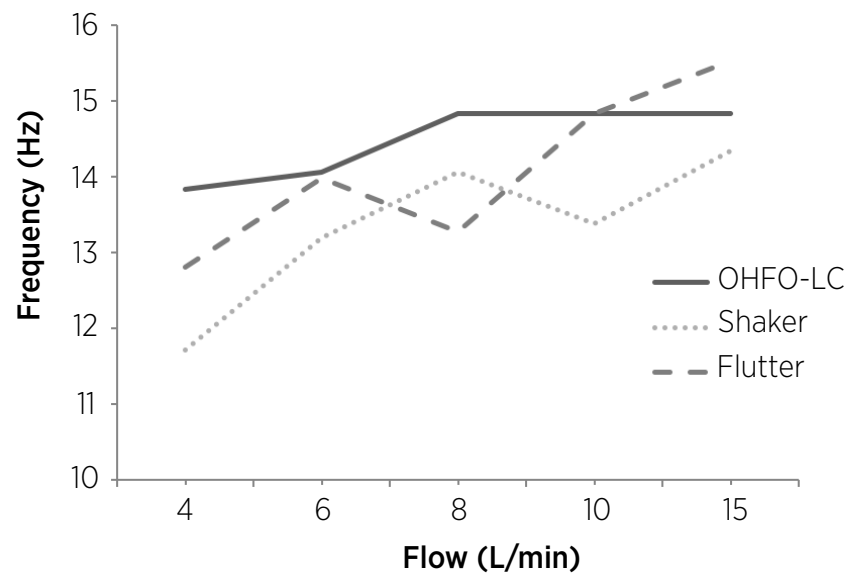

Figure 3. Frequencies of the three oral high-frequency oscillation (OHFO) devices

OHFO-LC: low-cost oral high-frequency oscillation. 


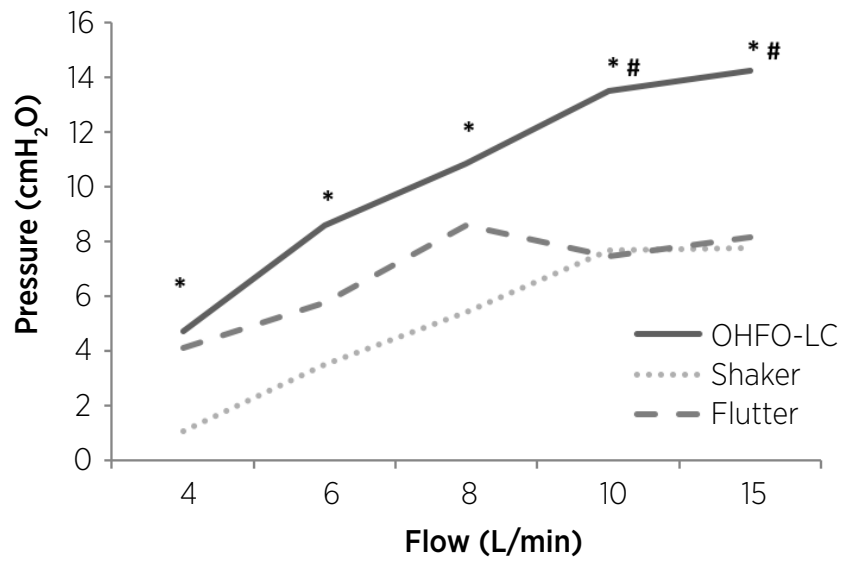

Figure 4. Pressures of the three oral high-frequency oscillation (OHFO) devices.

${ }^{*} \mathrm{p} \leq 0.05$ compared with Shaker; ${ }^{p} \mathrm{p} \leq 0.05$ compared with Flutter; OHFO-LC: low-cost oral highfrequency oscillation.

\section{DISCUSSION}

Our study showed the development of a low-cost handheld device (OHFO-LC) for airway clearance therapy (ACT) and demonstrated that it promoted a similar frequency but a higher positive expiratory pressure than those observed in oral high-frequency oscillation (OHFO) devices commercially available. Based on our findings, OHFO-LC could be considered for use in clinical practice and could be an option for patients with lower income.

We achieved our initial objective of developing a lowcost OHFO device, with a final cost of approximately US\$3. This cost is at least 6 times lower than the cost of the Shaker (NCS, Brazil) and over 15 times lower than that of the Flutter (Axcan Scandipharm Inc., USA). We emphasize that the cost of our equipment can be further reduced, especially if the spheres were purchased in larger quantities. We tried to replace the stainless steel sphere with iron spheres, which is cheaper; however, it oxidized after constant use and cleaning the sphere, hindering the hygiene of the equipment. It is important for ACT devices to avoid contamination to minimize the risk of infection.

Spheres manufactured from materials lighter than steel such as aluminum or Teflon (a type of plastic) do not reach the same pressure levels as the original stainless steel sphere in the Flutter VRP1 ${ }^{9}$. The OHFO-LC was built using polyvinyl chloride (PVC) because it is a low-cost, inert, nontoxic and malleable material ${ }^{7}$. Malleability is essential to allow the molding of the mouthpiece.

The ACT has been widely used in a variety of acute and chronic conditions, especially in patients with pulmonary hypersecretion ${ }^{10}$, to increase the quantity of expectorated mucus, prevent infections of the respiratory tract, and improve pulmonary function ${ }^{11-13}$. Thus, techniques allowing self-management for patients with hypersecretion are essential to the patient's independence in daily care ${ }^{14-16}$ and the need for hospital outpatient services. There are several techniques of ACT, but only few are considered appropriate for self-management (the slow expiration with glottis opened in lateral posture, the active cycle of breathing technique, the autogenic drainage and the OHFO devices). Among them, OHFO devices are being increasingly used ${ }^{14}$ and have some advantages such as portability, good acceptance by the patient, and applicability for non-supervised $\mathrm{use}^{2}$, including by adolescents and children ${ }^{3}$.

OHFO devices vibrate during the expiration, which mobilizes mucus ${ }^{17}$. The oscillatory frequencies in the commercially available OHFOs range from 12 to $15 \mathrm{~Hz}$, which is a similar to the physiological ciliary beat ${ }^{18,19}$; therefore, this vibration provides an optimal mucociliary clearance. Our results show that the frequency of the Shaker and Flutter ranged between 11.7 and $15.5 \mathrm{~Hz}$. OHFO-LC reached a similar frequency in all expiratory flows, showing similarity to the commercially available devices.

Positive expiratory pressure (PEP) is another important physiological effect in the OHFOs because it retains the air in the lung for a prolonged period, avoiding the collapse of the lung alveoli, improving the gaseous exchange and mobilizing secretion ${ }^{16,20}$. The PEP obtained using the OHFO-LC was higher when compared with the Shaker and Flutter VRP1, as showed in Figure 4. We think this may be a consequence of the weight of the stainless steel sphere, which is heavier when compared with the Shaker and Flutter (respectively, $42 \mathrm{~g}$ vs. $30 \mathrm{~g}$ and $28 \mathrm{~g}$ ). The higher PEP may be more beneficial due to air trapping reduction and facilitates the displacement of secretion in the airways.

Thompson et al. ${ }^{21}$ reported the patient's preference for using the $\mathrm{OHFO}$ when compared with the active cycle breathing technique. Moreover, a Cochrane review $^{22}$ showed that patients from 10 out of the 29 studies reported a preference for self-management airway clearance techniques. Patient's preference may improve their adherence to the treatment and induce greater benefits. Another Cochrane review indicated that increased adherence to a bronchial hygiene therapy may lead to improvements in clinical and functional parameters such as exercise tolerance and respiratory function ${ }^{17}$.

Our study has limitations. First, the airflow rates ranged from $4-15 \mathrm{~L} / \mathrm{min}$ due to measurement limitation of our experimental flow meter. However, that range is 
in the protocol used by Volsko, DiFiore and Chatburn ${ }^{8}$ (5-30 L/min), which performed the comparison of two oscillating expiratory positive pressure devices: Flutter vs Acapella. Second, previous studies ${ }^{1,2}$ compared the effects of the Shaker and Flutter and both have an internal cone to support the steel sphere, enabling device inclination; that is not the case in the OHFO-LC and the three devices were only compared at an angle of $0^{\circ}$ (parallel to the floor). On the other hand, this did not prevent OHFO-LC from reaching frequencies similar to those of the ciliary beat. We also consider that the assembly of the OHFO-LC requires the use of specific tools such as a drill, demanding caution when handling. At last, our results are preliminary since it is important to better understand the physiological effects of a novel device before exposing it to the patient.

Finally, a low-cost handheld OHFO device for the self-management of bronchial hypersecretion was developed and evaluated, showing similar frequencies and higher expiratory pressures than other commercially available OHFO devices. Further studies are necessary to evaluate its clinical efficacy.

\section{REFERENCES}

1. Volsko TA. Airway clearance therapy: finding the evidence. Respir Care. 2013;58(10):1669-78. doi: 10.4187/respcare.02590

2. dos Santos AP, Guimarães RC, de Carvalho EM, Gastaldi AC. Mechanical behaviors of flutter VRP1, shaker and acapella devices. Respir Care. 2013;58(2):298-304. doi: 10.4187/respcare.01685

3. Lee AL, Button BM, Tannenbaum EL. Airway-clearance techniques in children and adolescents with chronic suppurative lung disease and bronchiectasis. Front Pediatr. 2017;5:2. doi: 10.3389/fped.2017.00002

4. Flores JS, Teixeira FA, Rovedder PM, Ziegler B, Dalcin PT. Adherence to airway clearance therapies by adult cystic fibrosis patients. Respir Care. 2013;58(2):279-85. doi: 10.4187/respcare.01389

5. Myers TR. Positive expiratory pressure and oscillatory positive expiratory pressure therapies. Respir Care [Internet]. 2007 [cited 2019 Sept 18];52(10):1308-26. Available from: https:// www.ncbi.nlm.nih.gov/pubmed/17894901

6. Lindemann $\mathrm{H}$. The value of physical therapy with VRP 1-Desitin ("Flutter"). Pneumologie [Internet]. 1992 [cited 2019 Sept 18];46(12):626-30. Available from: https://www.ncbi.nlm.nih. gov/pubmed/1494580

7. Souza MA, Pessan LA, Rodolfo Jr A. Nanocompósitos de poli (cloreto de vinila) (PVC)/argilas organofílicas. Polímeros: Ciência e Tecnologia [Internet]. 2006 [cited 2019 Sept 18];16(4):257-62. Available from: http://www.scielo.br/pdf/po/v16n4/01.pdf
8. Volsko TA, DiFiore J, Chatburn RL. Performance comparison of two oscillating positive expiratory pressure devices: Acapella versus Flutter. Respir Care [Internet]. 2003 [cited 2019 Sept 18];48(2):124-30. Available from: https://www.ncbi.nlm.nih. gov/pubmed/12556253

9. de Lima LC, Duarte JB, Lépore Neto FP, Abe PT, Gastaldi AC. Mechanical evaluation of a respiratory device. Med Eng Phys. 2005;27(2):181-7. doi: 10.1016/j.medengphy.2004.09.016

10. Jones AP, Rowe BH. WITHDRAWN: Bronchopulmonary hygiene physical therapy for chronic obstructive pulmonary disease and bronchiectasis. Cochrane Database Syst Rev. 2011;(7):CD000045. doi: 10.1002/14651858.CD000045

11. van der Schans CP. Airway clearance: assessment of techniques. Paediatr Respir Rev 2002;3(2):110-4. https://doi.org/10.1016/ S1526-0550(02)00004-5

12. Hess DR. Secretion clearance techniques: absence of proof or proof of absence? Respir Care 2002;47(7):757-8. Available from: https://www.ncbi.nlm.nih.gov/pubmed/12088544

13. McCool FD, Rosen MJ. Nonpharmacologic airway clearance therapies: ACCP evidence-based clinical practice guidelines. Chest. 2006;129(1Suppl):250S-259S. doi: 10.1378/ chest.129.1_suppl.250S

14. Farbotko K, Wilson C, Watter P, MacDonald J. Change in physiotherapy management of children with cystic fibrosis in a large urban hospital. Physiother Theory Pract 2005;21(1):13-21. Available from: https://www.ncbi.nlm.nih.gov/ pubmed/16385940

15. Chatburn RL. High-frequency assisted airway clearance. Respir Care 2007:52(9):1224-35. Available from: https://www.ncbi. nlm.nih.gov/pubmed/17716388

16. Morrison L, Agnew J. Oscillating devices for airway clearance in people with cystics fibrosis. Cochrane Database Syst Rev. 2009;(1):CD006842. doi: 10.1002/14651858.CD006842.pub2

17. Morrison L, Agnew J. Oscillating devices for airway clearance in people with cystics fibrosis. Cochrane Database Syst Rev. 2014;(7):CD006842. doi: 10.1002/14651858.CD006842.pub3

18. Konstan MW, Stern RC, Doershuk CF. Efficacy of the flutter device for airway mucus clearance in patients with cystic fibrosis. J Pediatr. 1994;124:689-93. doi: 10.1016/s0022-3476(05)81356-3

19. Lubiński W, Targowski T, Frank-Piskorska A. Przydatność przyrzadu flutter VRP1 w rehabilitacji chorych na przewlekłe choroby układu oddechowego. Pol Merkuriusz Lek 2000;(43):37-40. Available from: https://journals.indexcopernicus.com/search/ article?articleld $=1060255$

20. Elkins MR, Jones A, van der Schans C. Positive expiratory pressure physiotherapy for airway clearance in people with cystic fibrosis. Cochrane Database Syst Rev. 2006;(2):CD003147. doi: 10.1002/14651858.CD003147.pub3

21. Thompson C, Harrison S, Ashley J, Day K, Smith D. Randomised crossover study of the flutter device and the active cycle of breathing technique in non-cystic fibrosis bronchiectasis. Thorax. 2002;57(5):446-8. doi: 10.1136/thorax.57.5.446

22. Main E, Prasad A, Schans C. Conventional chest physiotherapy compared to other airway clearance techniques for cystic fibrosis. Cochrane Database Syst Rev. 2005;(1):CD002011. doi:10.1002/14651858.CD002011.pub2 